\title{
17. THE MAGNETOSTRATIGRAPHY OF NORTHWEST PACIFIC SEDIMENTS, DEEP SEA DRILLING PROJECT LEG 86
}

\author{
Ulrich Bleil, Institut für Geophysik, Ruhr-Universität Bochum²
}

\begin{abstract}
Results of paleomagnetic analyses of pelagic sediment sequences recovered in the Northwest Pacific during Deep Sea Drilling Project Leg 86 are presented. On the basis of these data, almost complete late Cenozoic magnetostratigraphies are established for each drill site.

At Site 577, on the Shatsky Rise, a stratigraphic duplication of Late Cretaceous to middle Eocene sequences was achieved using the hydraulic piston coring technique. For the first time, a detailed paleomagnetic study of this period using largely undisturbed and complete sedimentary columns from the Pacific region was possible. Available biostratigraphy and stable isotope stratigraphy data allowed a positive correlation of the downhole magnetic reversal patterns with a calibrated geomagnetic polarity time scale. In general, the results obtained are in remarkable agreement with other recently published magnetostratigraphies from various parts of the world. Therefore, they represent a high quality framework for an early Tertiary magnetobiochronology including the Cretaceous/Tertiary boundary interval.
\end{abstract}

\section{INTRODUCTION}

Scientific objectives of Deep Sea Drilling Project (DSDP) Leg 86 were focused on the late Cenozoic paleoceanographic history of the western North Pacific. Four sites (Sites 578-581) were drilled on a north-south profile from subtropical to subarctic waters across the Kuroshio Current system. Additional operations included the recovery of a Late Cretaceous to Recent sedimentary sequence, containing the Cretaceous/Tertiary boundary, on the Shatsky Rise (Site 577) and a "type" red clay section east of this geologic structure (Site 576). Sites 576 to 580 were cored with the hydraulic piston corer (HPC), which allowed retrieval of mostly complete and undisturbed sediment sections. These materials provided high stratigraphic resolution for detailed biostratigraphic, magnetostratigraphic, and stable-isotope stratigraphic analyses.

The northern Pacific is one of the classic areas for paleomagnetic work on pelagic sediments; some of the pioneer paleomagnetic investigations using conventional piston cores (e.g., Opdyke, 1972) were done there. Because of the limited penetration capacity of this sampling technique, however, paleomagnetic studies typically have been restricted to the late Cenozoic period. A giant piston core containing pelagic red clay deposited during the entire Cenozoic was recently recovered in the mid-oceanic gyre region, but its magnetic record was inadequate to establish a magnetostratigraphy because the remanent magnetization became highly unstable only a few meters below the seafloor (Prince et al., 1980).

Despite relatively frequent DSDP operations in the northern Pacific, only sparse paleomagnetic results from rotary-cored materials have been published. Moreover,

\footnotetext{
${ }^{1}$ Heath, G. R., Burckle, L. H., et al., Init. Repts. DSDP, 86: Washington (U.S. Govt. Printing Office).

2 Address: Institut für Geophysik, Ruhr-Universităt Bochum, Postfach 102148, 4630 Bochum 1, Federal Republic of Germany.
}

the specific constraints imposed by this drilling method often reduced the quality and amount of the retrieved sediments and, consequently, the resolution of their magnetostratigraphies. On the other hand, very successful paleomagnetic studies have been completed on HPC materials recovered in the Caribbean (Kent and Spariosu, 1982a), the South Atlantic (Tauxe et al., 1984; Chave, 1984) and the Equatorial Pacific (Kent and Spariosu, $1982 \mathrm{~b}$; Weinreich and Theyer, in press).

This chapter includes magnetostratigraphic analyses of the predominantly calcareous nannofossil oozes penetrated in two holes at Site 577 (Holes 577 and 577A) and of the biosiliceous sediments of Sites 579 and 580 (Fig. 1). At all of these sites, the late Cenozoic is represented in extended sections, for which mostly complete and detailed magnetostratigraphic records were obtained. The Late Cretaceous to middle Eocene sequences, including the Cretaceous/Tertiary boundary epoch, recovered in the lower parts of Holes 577 and 577A made possible the first paleomagnetic study of this period on Pacific sedimentary suites.

The downhole patterns of magnetic reversals are correlated with the recently revised geomagnetic polarity time scale of Berggren et al. (in press). For pre-Neogene time, biostratigraphic and stable-isotope criteria had to be employed in places to positively identify a number of polarity intervals. In turn, the magnetostratigraphic data were used to elaborate numerical ages for coccolith event zonations calibrated on the basis of geomagnetic reversal boundary dates (Monechi et al., this volume). The results of detailed paleomagnetic work on the red clay sections encountered at Sites 576 and 578 are reported by Heath et al. (this volume).

\section{METHODS AND MATERIALS}

An extensive shipboard paleomagnetic sampling program was used for the sedimentary columns recovered at five drill sites (Sites 576 through 580 ) during Leg 86 . Vertically oriented specimens of about $7 \mathrm{~cm}^{3}$ were taken at intervals ranging from 10 to $50 \mathrm{~cm}$. The sample spacing typically represented time intervals on the order of $10^{4} \mathrm{yr}$. or less; in parts 


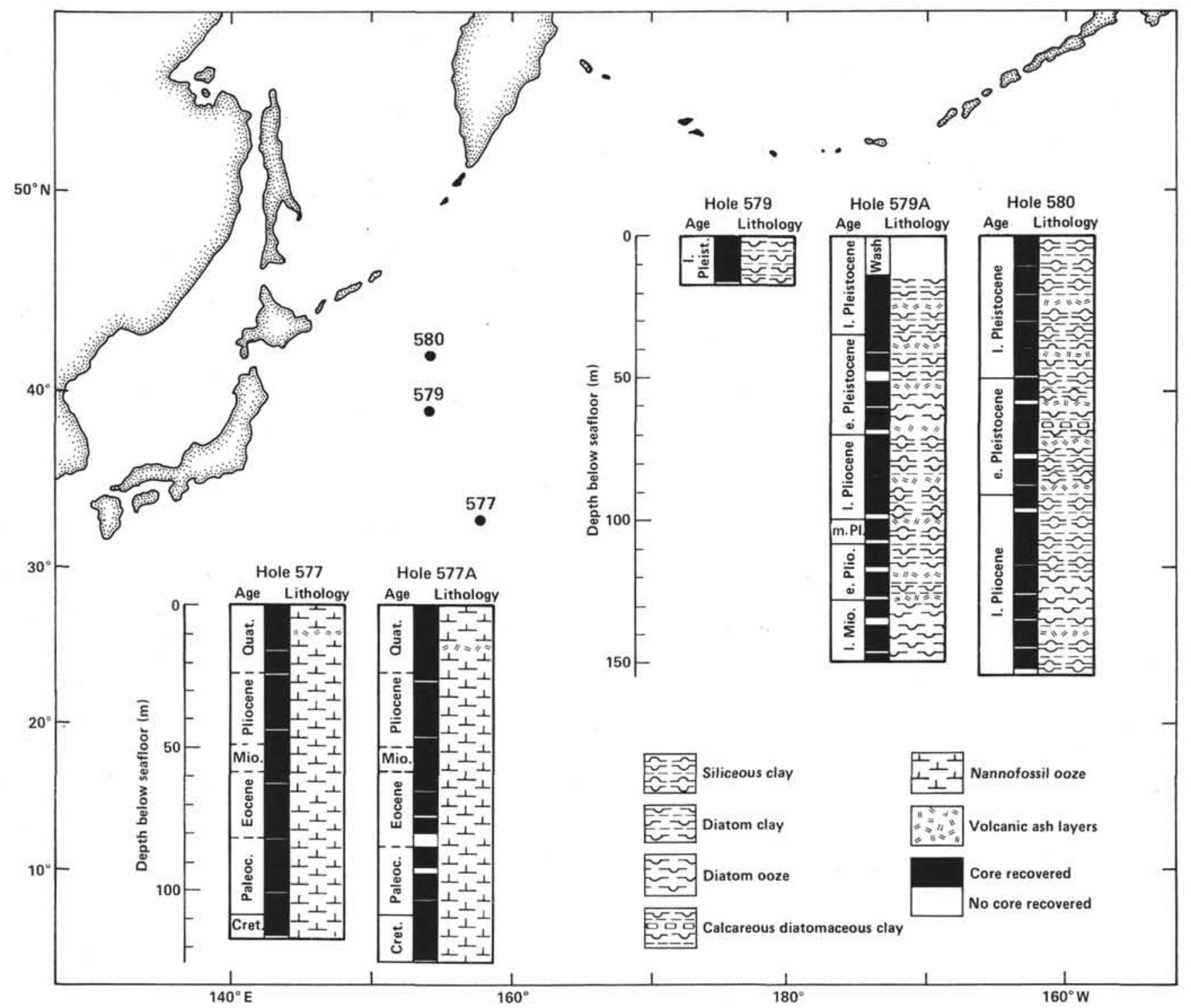

Figure 1. Location map of DSDP Leg 86 Sites 577, 579, and 580 together with schematic age, core recovery, and lithostratigraphy of sediments recovered by HPC.

of Sites 576 and 577 it increased to almost $10^{5} \mathrm{yr}$. The individual cubic samples, about $2 \mathrm{~cm}$ on edge, thus contain a paleomagnetic record of some $2 \times 10^{2}$ to approximately $10^{4} \mathrm{yr}$.

Because of the inadequate sensitivity of the Digico spinner magnetometer, shipboard paleomagnetic analyses had to be restricted to measurements of the natural remanent magnetization (NRM) direction without performing any demagnetization treatments. Depending on the sediment type, highly variable NRM intensities were encountered (see site reports, this volume). In general, clay and biosiliceous sediments carry a predominantly strong remanent magnetism, whereas increasing amounts of calcareous components result in a drastic reduction of the NRM intensity. A preliminary shipboard magnetostratigraphy, therefore, could be established only for the upper parts of Holes $576,576 \mathrm{~B}$, and 578 and for the complete sediment sequences in Holes $579,579 \mathrm{~A}$, and 580 .

Shore-based paleomagnetic work on clay sediments recovered at Sites 576 and 578 was completed by Heath et al. (this volume). Preliminary shipboard paleomagnetic results from these sites are reported in their respective site chapters (this volume). It is interesting to note that, even on the basis of the shipboard NRM data, meaningful magnetostratigraphies could be derived to appreciable depths $(\sim 20$ and $110 \mathrm{~m}$ sub-bottom at Sites 576 and 578 , respectively). This clearly contrasts with the observation made during previous studies that the magnetiza- tion of red clays in the central northern Pacific is generally unstable below a depth of about $5 \mathrm{~m}$ (Foster and Opdyke, 1970; Kent and Lowrie, 1974; Prince et al., 1980).

Samples from Sites 577,579 , and 580 were analyzed for their paleomagnetic properties at the Ruhr-University Bochum. Measurements of magnetization intensity and direction were made on a cryogenic magnetometer (Cryogenic Consultants, Model GM 400). A Schonstedt GSD-1 single axis demagnetizer was used for the alternating field (AF) demagnetization.

In addition to remeasurements of the NRM, systematic stepwise demagnetization treatments were carried out on each sample. For the bulk of the material, the demagnetization was taken to the 500 Oersted (Oe) level, which mostly exceeds the median destructive fields (MDF). Steps of 25 or 50 Oe were typically applied up to 100 Oe, followed by $50-$ Oe steps up to 200 or 300 Oe and 100 -Oe steps beyond that stage. Characteristic stable magnetization directions were evaluated from different graphic representations of the demagnetization data. The paleolatitudes of all drill sites permitted direct determination of the polarity sequence from the downhole pattern of stable inclinations. Although the "Kuster single-shot" orientation device was frequently employed during HPC operations on Leg 86, onshore paleomagnetic work revealed that the absolute azimuthal orientation data are basically useless. The instrument photographically fixes the position of a 
double-line mark on the core liner relative to a compass needle immediately before the stroke-out of the HPC barrel. However, any amount of random rotation is apparently possible between the position in this instantaneous photograph and the orientation of the azimuthal sediment magnetization finally found in the top part of the core liner. Moreover, downcore clockwise or counterclockwise rotations, sometimes even offsets of different magnitudes, are observed in the declination data (see also Weinreich and Theyer, in press). They are obviously produced by relative motions between sediment, core liner, or perhaps also the HPC barrel itself during stroke-out. As in former DSDP reports, therefore, only relative declinations could be defined with reference to the surface of the split core.

Shifts of $180^{\circ}$ in stable relative declinations were almost always found to coincide exactly with changes in sign of stable inclinations, further substantiating the identification of reversal boundaries. In the lower part of Holes 577 and 577A, however, only minor variations in declination are generally observed where stable inclinations indicate a polarity transition. Here, a uniform, presumably artificial magnetic overprinting could not be destroyed sufficiently by AF demagnetization. The spurious magnetization component is obviously approximately perpendicular to the split core surface, but any explanation of its origin seems speculative at present. Despite the likelihood that the individual inclination value may also be affected to varying degrees, the downhole variation in inclination polarity appears essentially to be preserved and a reliable magnetostratigraphy can be established, which is confirmed by the magnetostratigraphic duplication in the two adjacent holes drilled at Site 577.

The recently revised geomagnetic polarity time scale of Berggren et al. (in press) was used as a basis for the interpretation of the downhole polarity sequences and to define numerical ages for the reversal boundaries. In the late Cenozoic, the series of Earth's magnetic paleofield polarity intervals are specified according to the traditional "epoch" and "event" nomenclature (McDougall, 1977). The pre-Neogene magnetic time units are denoted as "chrons," following the recommendation of the Subcommission on Stratigraphic Classifications (Hedberg et al., 1979). In the terminology developed by Tauxe et al. (1984), a chron extends between the youngest reversal boundaries of a numbered marine magnetic anomaly as defined by Heirtzler et al. (1968) and revised by LaBrecque et al. (1977). The widely used number system for the anomaly pattern is thereby incorporated into this magnetostratigraphic time scale, and the chron unit is distinguished only by a prefix C. As to its definition, a chron includes not only the time interval of normal polarity corresponding to the respective anomaly number but also the preceding period of reversed polarity (see Fig. 7B). In order to denote the polarity zone, the suffix $\mathrm{N}$ (normal) or $\mathrm{R}$ (reversed) is added. Further subdivision into subchrons is needed where a chron comprises more than one normal or reversed polarity interval; for example C-23N-2 indicates the second (older) normal period within Chron 23.

\section{RESULTS}

Before discussing results ${ }^{3}$ for the different drill sites, some typical examples of the AF demagnetization response of the sediment types encountered during Leg 86 are briefly reviewed. At the same time, a general outline of the sediments' magnetization characteristics and the paleomagnetic methods used in this study is made.

At Sites 579 and 580, predominantly biosiliceous sediments were recovered (Fig. 1). As anticipated from the shipboard NRM data, their shore-based demagnetization treatment revealed a simple and uniform remanent magnetization structure (Type I behavior). Independent of their respective polarity, most of the samples showed a monotonous decrease in remanent magnetization intensity upon progressive AF demagnetization (Fig. 2A) with MDFs typically on the order of 250 Oe. The resultant vectors of magnetization, that is, the directions remaining after each demagnetization step, form a close cluster (Fig. 2B). Very minor scatter is also observed in the difference vectors (Hoffman and Day, 1978; Fig. 2C), that is, the magnetization directions removed by stepwise progressive demagnetization. In general, after a demagnetization to 50 or rarely to $100 \mathrm{Oe}$, the directions of resultant and difference vectors on average coincide, indicating the presence of an essentially single-component stable remanence. Additional proof for this interpretation was always obtained from Zijderveld (1967) vector diagrams. The characteristic stable inclination and de-

\footnotetext{
${ }^{3}$ Data on a sample-by-sample basis are available from the author on request.
}

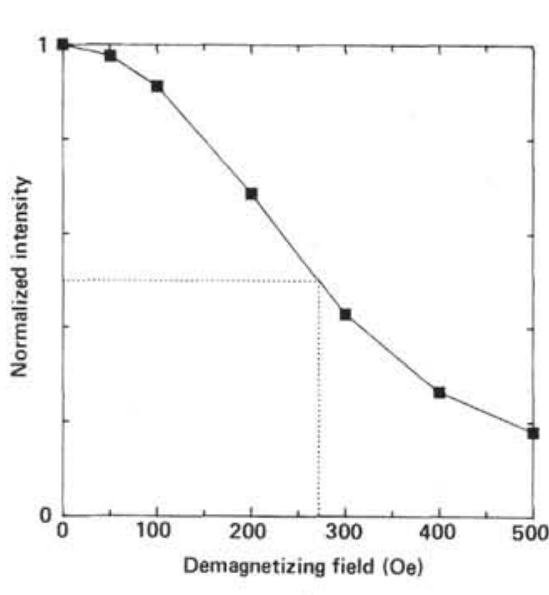

A

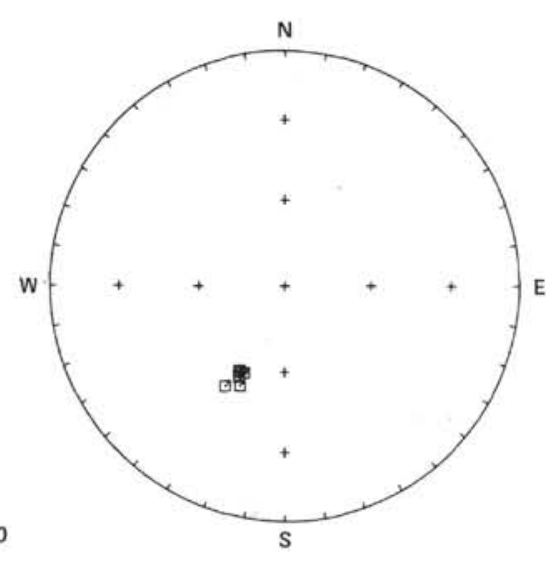

B

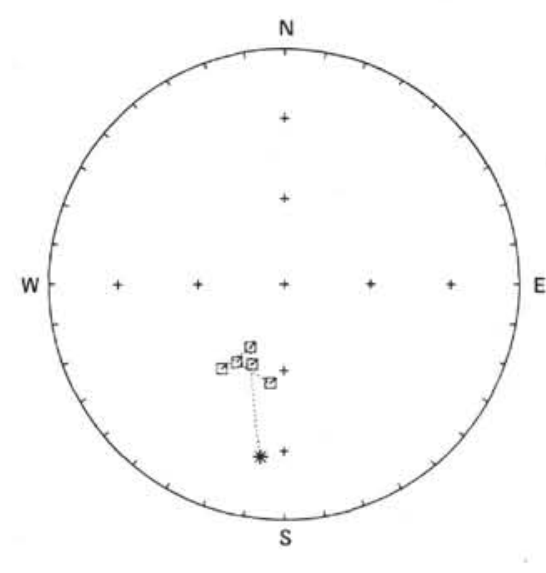

C

Figure 2. Demagnetization behavior of Sample 580-14-4, 139-141 cm. The results are characteristic of almost all the biosiliceous sediments penetrated at Sites 579 and 580 carrying a stable remanent magnetization (Type I behavior). A. NRM-normalized remanent magnetization intensity as a function of the applied demagnetizing field (in Oersted.) Dotted lines denote the MDF. B. Stereographic projection of the resultant vectors of magnetization. The asterisk indicates the NRM direction. Consecutive demagnetization steps are connected by great-circles. The respective AF increments may be read from Figure 2A. Open symbols represent negative inclinations. C. Stereographic projection of the difference vectors. The asterisk indicates the first demagnetization step, consecutive demagnetization steps are connected by great-circles. Open symbols represent negative inclinations. 
clination are determined for each sample from the demagnetization interval yielding the least directional scatter. A few samples from Sites 579 and 580 showed erratic characteristic directions. However, this is not because of an insufficient magnetic stability, but presumably results from disturbances introduced by the coring process.

In clear contrast, the predominantly calcareous oozes recovered in two holes at Site 577 frequently carry a multicomponent remanent magnetism. Here samples of reversed polarity typically show an increase of normalized magnetization intensity upon progressive AF demagnetization to 100 to $200 \mathrm{Oe}$, followed by a monotonous decrease beyond this stage (Fig. $3 \mathrm{~A}$ ). At the same time the resultant vectors gradually approach a consistent stable direction (Fig. 3B). Difference vector plots (Fig. 3C) show most clearly that two roughly antiparallel magnetization components are present in these samples. A magnetically less-stable fraction of normal polarity apparently results from a viscous magnetic overprinting during the Brunhes Epoch. It is mostly destroyed by alternating fields of 200 to 250 Oe after which the average resultant and difference vectors fall together, allowing determination of characteristic stable remanence directions. Again these results are always checked using Zijderveld (1967) diagrams. Note that in Figures 2 through 4, the declination data have been corrected by means of their respective core mean values to, on average, $180^{\circ}$ or $360^{\circ}$, thereby yielding a plausible relationship to the variations in sign of inclinations.

Many of the samples at Site 577 contain minor spurious unstable magnetization components, which do not show any directional consistency, however. Their magnetic stability is mostly even lower than the stability of those components tentatively identified as being of viscous origin. The unstable components may have been acquired, therefore, during handling, transport, or storage of the samples. Any multicomponent remanent magnetism from which characteristic stable directions can be discriminated is denoted as Type II behavior in this study.
An example of the Type III demagnetization response is shown in Figure 4. The demagnetization curve of these samples typically shows unsystematic variations in normalized remanent intensity (Fig. 4A). Both the resultant and difference vectors usually exhibit large directional changes upon progressive $\mathrm{AF}$ demagnetization, without ever attaining a clear-cut stable direction (Figs. 4B, 4C). These features have only been observed for a few samples in the calcareous oozes recovered at Site 577. They may not always reflect intrinsic magnetic properties of the sediments, however, since some physical disturbance is mostly indicated in the respective sampling intervals.

As mentioned before, detailed shore-based paleomagnetic analyses of the red clay sediments encountered at Sites 576 and 578 are presented by Heath et al. (this volume). In this chapter, therefore, only the preliminary shipboard magnetostratigraphies from those sites, based on NRM data, are listed in Tables 1 and 2. A brief discussion of these results is given in the appropriate site chapters (this volume).

\section{Site 577}

In two adjacent holes at Site 577, on the Shatsky Rise, a late Cenozoic and (separated by a major hiatus) a Maestrichtian to middle Eocene sequence of nannofossil oozes, including an undisturbed Cretaceous/Tertiary boundary interval were recovered. The upper $\sim 60$ $\mathrm{m}$ of the sedimentary column comprising the latest Miocene to Quaternary stratigraphic record contains subordinate amounts of volcanic ash and biosiliceous components (Fig. 1).

The paleomagnetic properties of almost 500 samples from Holes 577 and 577A were analyzed. On average, the NRM intensities are distinctly lower than those at the more northern sites of Leg 86 . On the other hand, their variability, both between and within cores, is less pronounced. The NRM intensity systematically decreases from about $15 \times 10^{-6} \mathrm{G}$ near the top to about $10^{-6} \mathrm{G}$ in the lower parts of both holes (Figs. 5 and 6). The overall geometric means amount to $2.7 \times 10^{-6}$ and 2.3

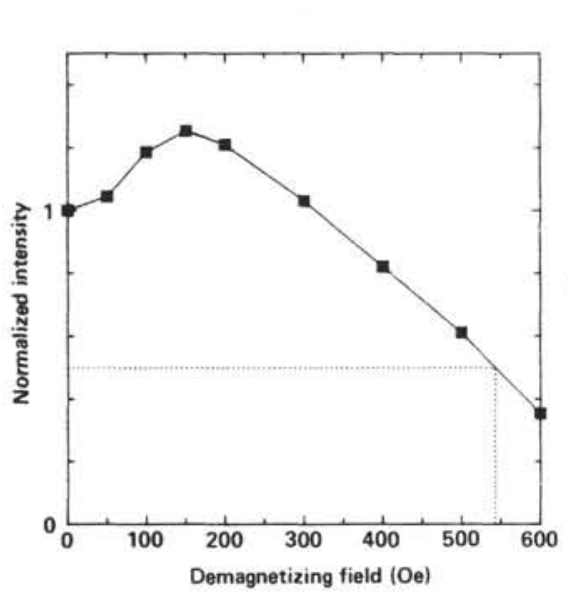

A

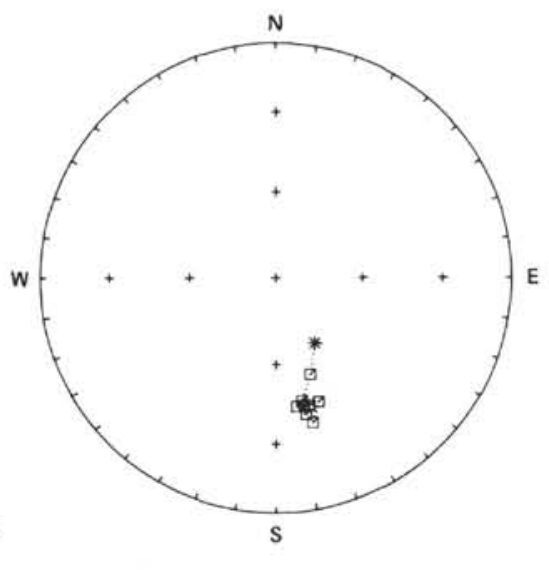

B

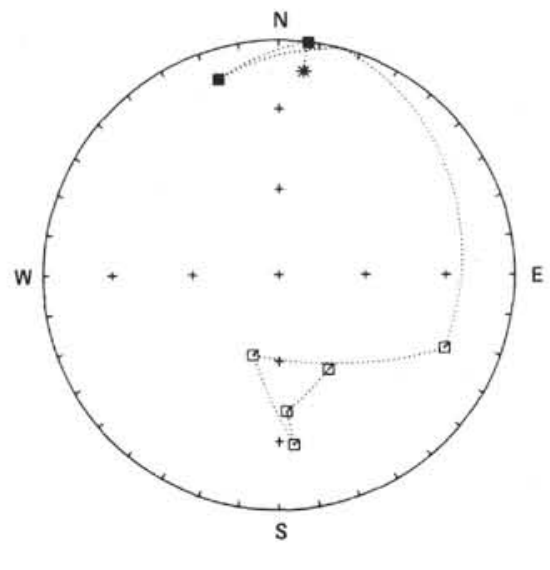

C

Figure 3. Demagnetization behavior of Sample $577-2-3,38-40 \mathrm{~cm}$. The results are characteristic of the majority of predominantly calcareous sediments recovered at Site 577 on the Shatsky Rise (Type II behavior). See caption of Figure 2 for details. Closed and open symbols in (A) and (B) represent positive and negative inclinations, respectively. 




A

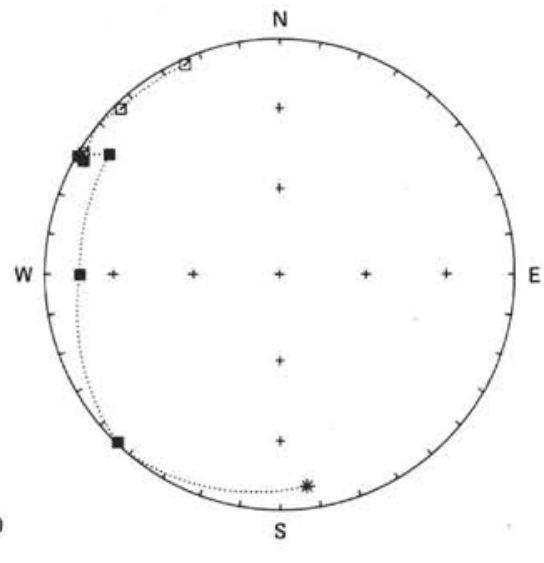

B

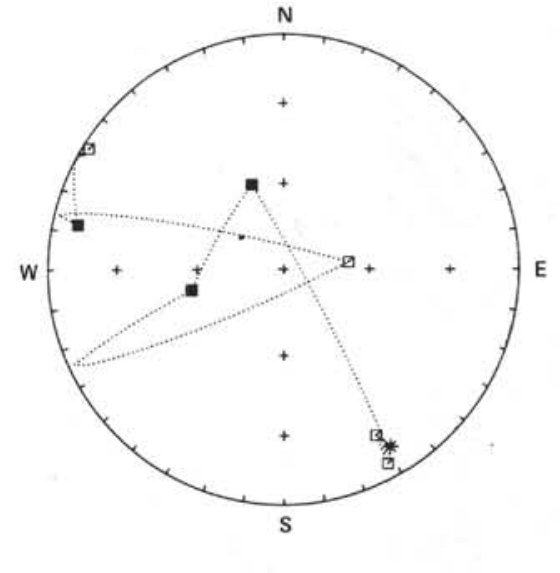

C

Figure 4. Demagnetization behavior of Sample 577A-5-3, 39-41 cm. The results are characteristic of sediments carrying an unstable remanent magnetization (Type III behavior). These features were only observed for a relatively small number of samples at Site 577. See caption of Figure 2 for details. Closed and open symbols in (A) and (B) represent positive and negative inclinations, respectively.

Table 1. Magnetostratigraphy of Holes 576 and 576B.

\begin{tabular}{llcc}
\hline \multicolumn{1}{c}{ Boundary } & $\begin{array}{c}\text { Age } \\
\text { (m.y.) }\end{array}$ & $\begin{array}{c}\text { Polarity transition }{ }^{\mathrm{b}} \\
\text { (Core, Section, level in cm) }\end{array}$ & $\begin{array}{c}\text { Corrected } \\
\text { sub-bottom } \\
\text { depth } \\
\text { (m) }\end{array}$ \\
\hline $\begin{array}{l}\text { Brunhes/Matuyama } \\
\text { Jaramillo }\end{array}$ & 0.73 & $1-5,85$ to $1-5,106^{\mathrm{d}}$ & 6.95 \\
$\begin{array}{l}\text { top } \\
\text { bottom }\end{array}$ & 0.91 & $2-2,26$ to $2-2,36^{\mathrm{e}}$ & 9.01 \\
$\begin{array}{l}\text { Olduvai } \\
\text { top } \\
\text { bottom }\end{array}$ & 0.98 & $2-2,106$ to $2-2,116^{\mathrm{e}}$ & 9.81 \\
$\begin{array}{l}\text { Matuyama/Gauss } \\
\text { Matuyam }\end{array}$ & 1.66 & $2-6,26$ to $2-6,46^{\mathrm{e}}$ & 15.06 \\
\hline
\end{tabular}

a Berggren et al. (in press).

b Range reflects uncertainty in determination.

c See Site 576 chapter (this volume) for details.

d Hole 576B.

e Hole 576.

$\times 10^{-6} \mathrm{G}$ in Holes 577 and $577 \mathrm{~A}$, respectively. A significant difference of roughly a factor of two in the averages for normal and reversed polarities is observed in the late Cenozoic period, but not in the older sediment sequences. The magnetic stability characterized by the MDF displays the opposite trends. These findings reflect the negative interaction of bipolar magnetization components reducing the NRM intensity. In turn, MDF reached at $50 \%$ NRM (Fig. 3) is too high as compared to an MDF at $50 \%$ of the sum of all magnetization amounts initially present. However, because of the complex magnetization structure in many samples of Site 577, no attempt has been made to quantify this latter, physically more rational parameter from the demagnetization curves. In the upper $\sim 60 \mathrm{~m}$, although extremely variable, the MDFs yield a geometric mean of $295 \mathrm{Oe}$, more than twice that of the Late Cretaceous to Paleogene period (132 Oe).

AF demagnetization frequently resulted in large directional changes in remanent magnetization directions. In the latest Cenozoic portion, secondary magnetization components could mostly be identified as originating from a viscous overprinting in the Brunhes Epoch, at
Table 2. Magnetostratigraphy of Hole 578.

\begin{tabular}{|c|c|c|c|}
\hline Boundary ${ }^{a}$ & $\begin{array}{l}\text { Ageb } \\
\text { (m.y.) }\end{array}$ & $\begin{array}{c}\text { Polarity transition }{ }^{c} \\
\text { (Core, Section, level in } \mathrm{cm} \text { ) }\end{array}$ & $\begin{array}{l}\text { Sub-bottom } \\
\text { depthd } \\
\text { (m) }\end{array}$ \\
\hline $\begin{array}{l}\text { Brunhes/Matuyama } \\
\text { Jaramillo }\end{array}$ & 0.73 & $4-3,65$ to $4-3,105$ & 27.66 \\
\hline top & 0.91 & $4-6,46$ to $4-6,66$ & 31.86 \\
\hline bottom & 0.98 & $5-1,106$ to $5-1,126$ & 34.46 \\
\hline \multicolumn{4}{|l|}{ Olduvai } \\
\hline top & 1.66 & $7-2,28$ to $7-2,46$ & 54.17 \\
\hline bottom & 1.88 & $7-4,126$ to $7-4,146$ & 58.16 \\
\hline Matuyama/Gauss & 2.47 & $9-1,126$ to $9-1,146$ & 72.66 \\
\hline \multicolumn{4}{|l|}{ Kaena } \\
\hline top & 2.92 & $9-7,26$ to $9-7,48$ & 80.67 \\
\hline bottom & 2.99 & $10-2,6$ to $10-2,24$ & 82.45 \\
\hline \multicolumn{4}{|l|}{ Mammoth } \\
\hline top & 3.08 & $10-2,126$ to $10-2,146$ & 83.66 \\
\hline bottom & 3.18 & $10-3,106$ to $10-3,146$ & 85.06 \\
\hline Gauss/Gilbert & 3.40 & $10-5,66$ to $10-5,106$ & 87.66 \\
\hline \multicolumn{4}{|l|}{ Cochiti } \\
\hline top & 3.88 & $11-2,146$ to $11-3,26$ & 93.41 \\
\hline bottom & 3.97 & $11-3,126$ to $11-4,6$ & 94.71 \\
\hline \multicolumn{4}{|l|}{ Nunivak } \\
\hline top & 4.10 & $11-5,6$ to $11-5,46$ & 96.56 \\
\hline bottom & 4.24 & $11-5,116$ to $11-6,6$ & 97.66 \\
\hline \multicolumn{4}{|l|}{ Sidufjall } \\
\hline top & 4.40 & $11-6,126$ to $11-7,6$ & 99.21 \\
\hline bottom & 4.47 & $12-2,4$ to $12-2,51$ & 101.58 \\
\hline \multicolumn{4}{|l|}{ Thvera } \\
\hline top & 4.57 & $12-2,106$ to $12-2,146$ & 102.56 \\
\hline bottom & 4.77 & $12-4,6$ to $12-4,46$ & 104.56 \\
\hline Gilbert/Epoch 5 & 5.35 & $12-6,140$ to $13-1,46$ & 109.23 \\
\hline
\end{tabular}

a Terminology according to McDougall (1977).

b Berggren et al. (in press).

c Range reflects uncertainty in determination.

d From coring summary, see Table 1 of Site 578 chapter (this volume).

least for samples carrying a reversed polarity (Fig. 3). In contrast, in the older sedimentary sequences, unstable magnetization components typically did not show much directional consistency (Fig. 4). In the older sediments, the poor magnetic stability mentioned obviously led to the acquisition of spurious remanences during and/or after recovery of the cores. The relatively large scatter in directional data likely indicates that the stable directions defined are not always true primary, single-component magnetizations, but also include some secondary com- 


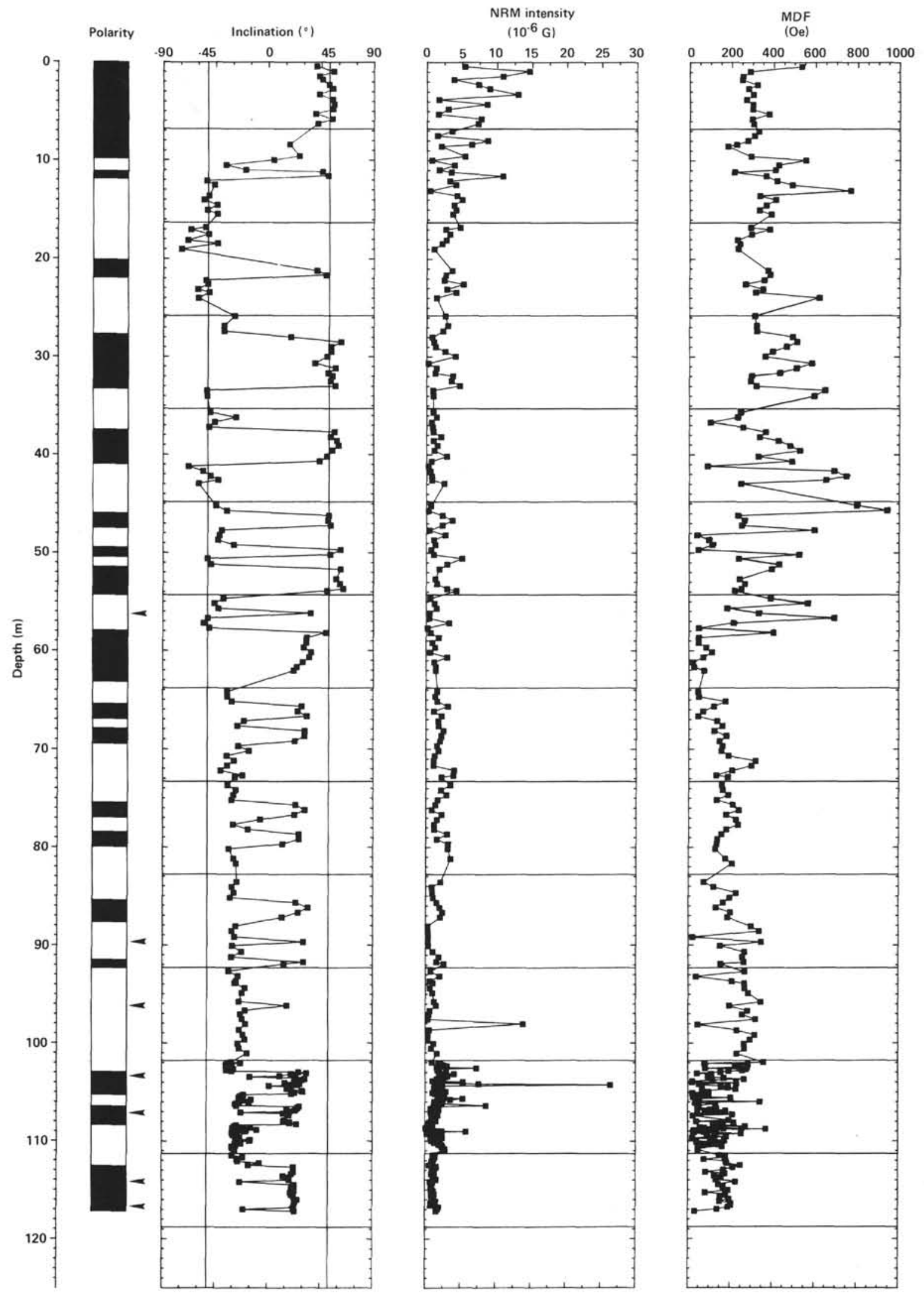

Figure 5. Stratigraphic column of Hole 577 showing the variations in inclination of the characteristic remanent magnetization, in NRM intensity, and in MDF. Horizontal lines indicate core boundaries. The two vertical lines in the stable inclination log denote the geocentric axial dipole values for the present latitude of the drill site. The paleomagnetic polarity log is based on stable inclinations, black being normal and white being reversed polarity. The arrows are explained in the text. 

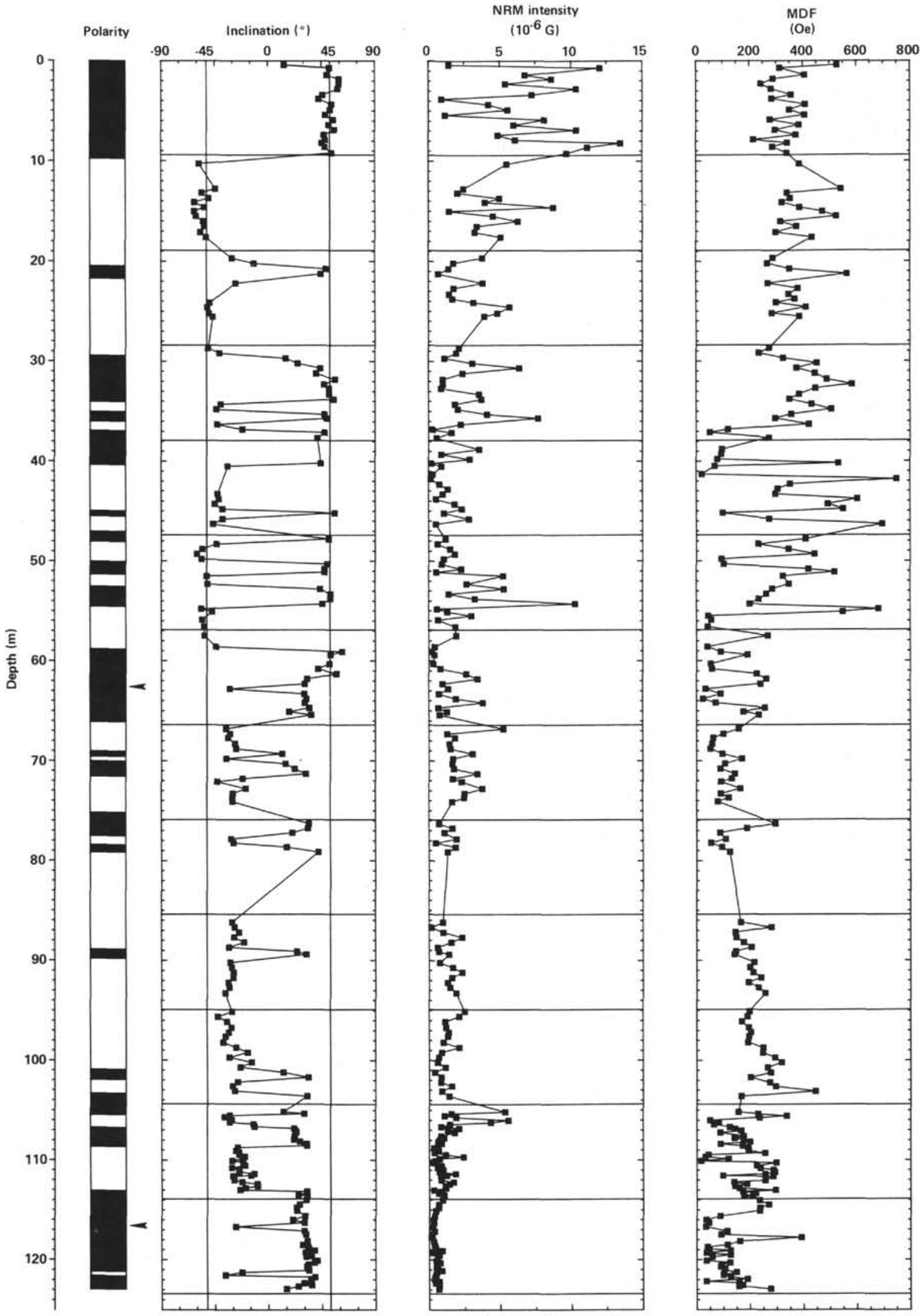

Figure 6. Stratigraphic column of Hole 577A. See caption of Figure 5 for details. 
ponents that could not be erased completely by AF demagnetization. Such effects should not greatly reduce the quality of the magnetostratigraphies derived, but make the results a rather poor choice for paleosecular variation and paleolatitude analyses.

In the upper part of the cored sections, the downhole pattern of characteristic remanent magnetization inclination yields an almost unequivocal reversal stratigraphy for about the last 5.5 m.y. (Figs. 5, 6, and 7A). That stratigraphy includes all major transitions of the Earth's magnetic field since the beginning of the Gilbert Epoch. However, because of limited recovery or badly disturbed sediments in some cores of both holes, appreciable uncertainty exists in defining exact depth positions for a number of reversal boundaries (Table 3). For the same reason, the following short polarity events are missing in one hole but can be recognized in the other: in Hole 577 the normal interval separating the Kaena and Mammoth events in the middle of the Gauss Epoch and the Cochiti Event in the Gilbert Epoch, and in Hole 577A, the Jaramillo Event in the late Matuyama Epoch.

A comparison of depth positions for several well-defined reversals in both holes reveals variable degrees of mutual offsets amounting to at least $\pm 1 \mathrm{~m}$ downhole (Fig. 7A). Although this could effectively be the result of real fluctuations in paleotopography, it can also be explained by the standard DSDP procedure of accounting for any material loss at the base of each cored interval.

The depth position for the last occurrence of the calcareous nannofossil Discoaster quinqueramus in the early part of the Gilbert Epoch (Monechi et al., this volume) disagrees with most other published results. In general, this coccolith datum level has been observed near the middle of Epoch 5. There is a possibility, therefore, that the normal polarity interval identified as the Thvera Event here could be the late part of Epoch 5. Without further evidence, this interpretation was rejected mainly because it requires both a drastic change in sedimentation rate and rather complicated arguments concerning the remaining magnetobiostratigraphic sequence around this level.

To about $60 \mathrm{~m}$ below seafloor, the sedimentary column apparently accumulated at a remarkably constant average rate of about $11 \mathrm{~m} / \mathrm{m} . \mathrm{y}$. The sedimentation rates were slightly higher in the Brunhes and Gauss Epochs and lower in the Gilbert Epoch, but any shift is limited to within $30 \%$ of the average (Fig. 7A).

At around $62 \mathrm{~m}$ sub-bottom, a major hiatus separates latest Miocene from middle Eocene sediments (Monechi, this volume; Site 577 report, this volume). Calcareous nannofossils suggest additional shorter hiatuses in the early Eocene and near the Paleocene/Eocene boundary (Monechi, this volume). Detailed correlations of biostratigraphic and paleomagnetic marker horizons in the sedimentary columns of both holes also revealed missing intervals at the boundary of Cores 8 and 9 of Hole 577 and within Core 10 of Hole 577A, each about 2.6-m long, that are not listed in the coring record (Monechi et al., this volume). Further complicated by an incomplete or badly disturbed recovery at several levels, for the lower halves of both holes and in particular for the Eocene period, magnetostratigraphies could only be established in the framework of biostratigraphic and stable-isotope stratigraphy (Shackleton et al., this volume) data.

The first positively identified magnetic polarity zone beneath the major unconformity is the C-22N subchron in Hole 577, corresponding to the marine magnetic Anomaly 22 . In this hole, with the exception of the two normal polarity intervals of the C-23 and C-27N subchrons, a virtually complete reversal sequence was identified ending in the Late Cretaceous $\mathrm{C}-30 \mathrm{~N}$ subchron near the base of the hole (Figs. 5 and 7B). In Hole 577A, only the C- $22 \mathrm{~N}$ and $\mathrm{C}-25 \mathrm{~N}$ subchrons could not be recognized (Figs. 6 and 7B), which was evidently the result of a lack of recovery in the relevant intervals. At the base of this slightly deeper hole, the magnetostratigraphic record reaches into the $\mathrm{C}-31 \mathrm{~N}$ subchron. The above-described difficulties caused relatively large ranges of uncertainty in defining the depth of a number of reversal boundaries in both holes (Table 3).

At different levels in Holes 577 and 577A, short polarity events are indicated in the downhole patterns of the characteristic remanent magnetization inclinations. They are denoted by small arrows at the magnetostratigraphic columns in Figures 5 and 6. As no consistency exists in these data between the two holes, no attempt was made for a correlation with similar paleomagnetic results from Site 524 in the South Atlantic (Tauxe et al., 1984 ) or with the "tiny wiggles" in the polarity time scale of LaBrecque et al. (1977).

On the basis of biostratigraphic evidence, the Cretaceous/Tertiary boundary was recognized at 109.10 and $109.62 \mathrm{~m}$ depth below seafloor in Holes 577 and 577A, respectively. In both holes the boundary is located within the interval of reversed polarity that separates the marine magnetic Anomalies 29 and 30, denoted as the C$29 \mathrm{R}$ subchron in the presently used nomenclature. Worldwide, the same result was obtained from analyses of various marine sections (Alvarez et al., 1977; Alvarez and Lowrie, 1978; Hsü et al., 1982; Shackleton et al., 1984; Thierstein, 1982 and references therein). As pointed out by Thierstein (1982), the relative position of the paleontological boundary within the magnetic C-29R subchron is highly variable in different pelagic sequences, indicating major changes in sedimentation rate and/or the possible presence of hiatuses. Similar to the situation in most of these sections, the C-29R subchron is expanded in the sedimentary column recovered at Site 577 relative to the preceding C-30N and the following C-29N normal polarity subchrons. A numerical age determined for the Cretaceous/Tertiary boundary horizon by interpolation from the magnetic C-29R boundaries and by extrapolation downward using the C-29N and upward using the C-30N boundary varies between about 66.3 and $66.5 \mathrm{~m} . \mathrm{y}$. This is in complete agreement with other recent estimates based on the same time scale (Berggren et al., in press; Shackleton et al., 1984).

Since it was only possible to elaborate a rather crude magnetostratigraphy for the Eocene, the apparent sedimentation rates derived from the paleomagnetic data for this period are of relatively poor quality (Fig. 7B). They 
A


Figure 7. Apparent sediment accumulation at Site 577. $\odot$ Hole 577, $\square$ Hole 577A. The downhole pattern in remanent magnetization polarity is correlated to the geomagnetic polarity time scale of Berggren et al. (in press). A. Late Cenozoic. Geomagnetic time units (epochs, events) according to McDougall (1977). B. Late Cretaceous to middle Eocene. Geomagnetic time units (chrons) according to Tauxe et al. (1984). 
Table 3. Magnetostratigraphy of Holes 577 and 577A.

\begin{tabular}{|c|c|c|c|c|c|}
\hline \multirow[b]{2}{*}{ Boundary ${ }^{a}$} & \multirow[b]{2}{*}{$\begin{array}{l}\text { Ageb } \\
(\mathrm{m} . \mathrm{y} .)\end{array}$} & Hole 577 & \multirow[b]{2}{*}{$\begin{array}{l}\text { Sub-bottom } \\
\text { depthd } \\
\text { (m) }\end{array}$} & \multicolumn{2}{|l|}{ Hole 577A } \\
\hline & & $\begin{array}{c}\text { Polarity transitionc } \\
\text { (Core, Section, level in } \mathrm{cm} \text { ) }\end{array}$ & & $\begin{array}{c}\text { Polarity transition } \mathrm{c} \\
\text { (Core, Section, level in } \mathrm{cm} \text { ) }\end{array}$ & $\begin{array}{l}\text { Sub-bottom } \\
\text { depthd } \\
\text { (m) }\end{array}$ \\
\hline Brunhes/Matuyama & 0.73 & $2-2,130$ to $2-3,20$ & 9.80 & $1-7,22$ to $2-1,89$ & 9.76 \\
\hline \multicolumn{6}{|l|}{ Jaramillo } \\
\hline top & 0.91 & $2-3,119$ to $2-3,140$ & 11.10 & - & - \\
\hline bottom & 0.98 & $2-4,30$ to $2-4,80$ & 11.85 & - & - \\
\hline \multicolumn{6}{|l|}{ Olduvai } \\
\hline top & 1.66 & $3-2,120$ to $3-4,41$ & 20.11 & $3-1,129$ to $3-2,35$ & 20.47 \\
\hline bottom & 1.88 & $3-4,85$ to $3-4,140$ & 21.93 & $3-2,85$ to $3-3,30$ & 21.73 \\
\hline Matuyama/Gauss & 2.47 & $4-2,10$ to $4-2,70$ & 27.70 & $4-1,79$ to $4-1,130$ & 29.45 \\
\hline \multicolumn{6}{|l|}{ Kaena } \\
\hline top & 2.92 & $4-5,120$ to $4-6,14$ & 33.22 & $4-4,90$ to $4-4,140$ & 34.05 \\
\hline bottom & 2.99 & - & - & $4-5,40$ to $4-5,90$ & 35.05 \\
\hline \multicolumn{6}{|l|}{ Mammoth } \\
\hline top & 3.08 & - & - & $4-5,130$ to $4-6,40$ & 36.00 \\
\hline bottom & 3.18 & $5-2,41$ to $5-2,90$ & 37.46 & $4-6,90$ to $4-6,120$ & 36.95 \\
\hline Gauss/Gilbert & 3.40 & $5-4,90$ to $5-4,140$ & 40.95 & $5-2,80$ to $5-2,110$ & 40.35 \\
\hline \multicolumn{6}{|l|}{ Cochiti } \\
\hline top & 3.88 & - & - & $5-5,90$ to $5-5,130$ & 45.00 \\
\hline bottom & 3.97 & - & - & $5-5,130$ to $5-6,40$ & 45.50 \\
\hline \multicolumn{6}{|l|}{ Nunivak } \\
\hline top & 4.10 & $6-1,90$ to $6-1,140$ & 45.95 & $5-6,90$ to $6-1,40$ & 47.05 \\
\hline bottom & 4.24 & $6-2,90$ to $6-2,140$ & 47.45 & $6-1,40$ to $6-1,90$ & 48.05 \\
\hline \multicolumn{6}{|l|}{ Sidufjall } \\
\hline top & 4.40 & $6-3,140$ to $6-4,40$ & 49.45 & $6-2,90$ to $6-2,140$ & 50.05 \\
\hline bottom & 4.47 & $6-4,90$ to $6-4,130$ & 50.40 & $6-3,70$ to $6-3,110$ & 51.30 \\
\hline \multicolumn{6}{|l|}{ Thvera } \\
\hline top & 4.57 & $6-5,40$ to $6-5,90$ & 51.45 & $6-4,40$ to $6-4,90$ & 52.55 \\
\hline bottom & 4.77 & $6-7,9$ to $7-1,40$ & 54.30 & $6-5,90$ to $6-5,140$ & 54.55 \\
\hline Gilbert/Epoch 5 & 5.35 & $7-3,40$ to $7-3,90$ & 57.95 & $7-2,20$ to $7-2,70$ & 58.85 \\
\hline$?(\mathrm{~N} / \mathrm{R})$ & $?$ & $7-6,26$ to $8-1,40$ & 63.13 & - & - \\
\hline \multicolumn{6}{|l|}{$\mathrm{C}-17$ or $\mathrm{C}-18$} \\
\hline$(\mathrm{R} / \mathrm{N})$ & $?$ & $8-1,140$ to $8-2,40$ & 65.45 & - & - \\
\hline (N/R) & $?$ & $8-2,140$ to $8-3,40$ & 66.95 & $7-6,100$ to $8-1,40$ & 66.10 \\
\hline$? / \mathrm{C}-22 \mathrm{~N}$ & 51.95 & $8-3,90$ to $8-3,140$ & 67.95 & - & - \\
\hline $\mathrm{C}-22 \mathrm{~N} / \mathrm{C}-22 \mathrm{R}$ & 52.62 & $8-4,90$ to $8-4,140$ & 69.45 & - & - \\
\hline $\mathrm{C}-22 \mathrm{R} / \mathrm{C}-23 \mathrm{~N}-1$ & 53.88 & - & - & $8-2,90$ to $8-2,140$ & 69.05 \\
\hline $\mathrm{C}-23 \mathrm{~N}-1 / \mathrm{C}-23 \mathrm{R}-1$ & 54.03 & - & - & $8-2,140$ to $8-3,40$ & 69.55 \\
\hline C-23R-1/C-23N-2 & 54.09 & - & - & $8-3,40$ to $8-3,90$ & 70.05 \\
\hline C- $23 \mathrm{~N}-2 / \mathrm{C}-23 \mathrm{R}-2$ & 54.70 & - & - & $8-4,40$ to $8-4,90$ & 71.55 \\
\hline C- $23 \mathrm{R}-2 / \mathrm{C}-24 \mathrm{~N}-1$ & 55.14 & $9-2,40$ to $9-2,90$ & 75.45 & $8-6,20$ to $9-1,41$ & 75.21 \\
\hline $\mathrm{C}-24 \mathrm{~N}-1 / \mathrm{C}-24 \mathrm{R}-1$ & 55.37 & $9-3,40$ to $9-3,90$ & 76.95 & $9-1,131$ to $9-2,44$ & 77.53 \\
\hline C $-24 \mathrm{R}-1 / \mathrm{C}-24 \mathrm{~N}-2$ & 55.66 & $9-4,40$ to $9-4,90$ & 78.45 & $9-2,82$ to $9-2,125$ & 78.44 \\
\hline C $-24 \mathrm{~N}-2 / \mathrm{C}-24 \mathrm{R}-2$ & 56.14 & $9-5,40$ to $9-5,90$ & 79.95 & - & - \\
\hline C- $-24 \mathrm{R}-2 / \mathrm{C}-25 \mathrm{~N}$ & 58.64 & $10-2,90$ to $10-2,140$ & 85.45 & - & - \\
\hline $\mathrm{C}-25 \mathrm{~N} / \mathrm{C}-25 \mathrm{R}$ & 59.24 & $10-3,140$ to $10-4,80$ & 87.65 & - & - \\
\hline$C-25 \mathrm{R} / \mathrm{C}-26 \mathrm{~N}$ & 60.21 & $10-6,92$ to $10-6,142$ & 91.47 & $10-3,30$ to $10-3,71$ & 88.91 \\
\hline$C-26 \mathrm{~N} / \mathrm{C}-26 \mathrm{R}$ & 60.75 & $10-7,11$ to $11-1,39$ & 92.30 & $10-3,100$ to $10-4,31$ & 89.81 \\
\hline$C-26 \mathrm{R} / \mathrm{C}-27 \mathrm{~N}$ & 63.03 & - & - & $11-4,130$ to $11-5,30$ & 100.95 \\
\hline$C-27 N / C-27 R$ & 63.54 & - & - & $11-5,80$ to $11-5,130$ & 101.95 \\
\hline$C-27 R / C-28 N$ & 64.29 & $12-1,110$ to $12-1,120$ & 102.95 & $11-6,70$ to $11-6,120$ & 103.35 \\
\hline C- $28 \mathrm{~N} / \mathrm{C}-28 \mathrm{R}$ & 65.12 & $12-3,40$ to $13-3,50$ & 105.25 & $12-1,96$ to $12-1,116$ & 105.46 \\
\hline$C-28 \mathrm{R} / \mathrm{C}-29 \mathrm{~N}$ & 65.50 & $12-4,10$ to $12-4,20$ & 106.45 & $12-2,76$ to $12-2,94$ & 106.75 \\
\hline C- $29 \mathrm{~N} / \mathrm{C}-29 \mathrm{R}$ & 66.17 & $12-5,50$ to $12-5,60$ & 108.35 & $12-3,116$ to $12-3,135$ & 108.66 \\
\hline C- $29 \mathrm{R} / \mathrm{C}-30 \mathrm{~N}$ & 66.74 & $13-1,120$ to $13-1,140$ & 112.60 & $12-6,111$ to $12-6,126$ & 113.09 \\
\hline C $-30 N / C-30 R$ & 68.42 & - & - & $13-5,119$ to $13-5,137$ & 121.18 \\
\hline C-30R/C-31N & 68.52 & - & - & $13-6,15$ to $13-6,35$ & 121.65 \\
\hline
\end{tabular}

Note: - means not recovered.

a Terminology according to McDougall (1977) and Tauxe et al. (1984).

b Berggren et al. (in press).

c Range reflects uncertainty in determination.

d From coring summary, see Table 1 of Site 577 chapter (this volume).

yield an average sedimentation rate of $3.5 \mathrm{~m} / \mathrm{m} . \mathrm{y}$. in Hole 577 and $5.3 \mathrm{~m} / \mathrm{m} . \mathrm{y}$. in Hole 577A. During the Paleocene, the sediments accumulated at an average rate of about $3 \mathrm{~m} / \mathrm{m} . \mathrm{y} .(3.0 \mathrm{~m} / \mathrm{m} . \mathrm{y}$. and $3.3 \mathrm{~m} / \mathrm{m}$.y. in Holes 577 and $577 \mathrm{~A}$, respectively). In detail, the magnetostratigraphic record indicates that the variability in sedimentation rate during the early Tertiary was mostly within a factor of two. The apparent accumulation rate increases to about $7.6 \mathrm{~m} / \mathrm{m} . \mathrm{y}$. in the C-29R subchron containing the Cretaceous/Tertiary boundary horizon. According to the data from Hole 577A, on average it amounts to 4.8 $\mathrm{m} / \mathrm{m}$.y. in the Late Cretaceous.

\section{Site 579}

At Site 579, $149 \mathrm{~m}$ of early Pliocene to Quaternary biosiliceous clays with numerous interlayered volcanic ashes were penetrated in two holes using the HPC (Fig. 1). Because of marginal weather conditions, the sedi- 
ments were frequently distorted, stretched, or otherwise disturbed. The recovery was distinctly below the average for Leg 86 , only about $80 \%$ in many cores.

About 300 vertically oriented samples were analyzed for their paleomagnetic properties. The NRM intensity was extremely variable throughout the section. Continuous downhole trends of decreasing NRM intensity from about $4 \times 10^{-5}$ to about $4 \times 10^{-6} \mathrm{G}$ occur in the uppermost $\sim 60 \mathrm{~m}$ spanning the Brunhes and the latter half of the Matuyama epochs, and from about $3 \times 10^{-5}$ to about $10^{-6} \mathrm{G}$ below $95 \mathrm{~m}$ sub-bottom to the base of Hole 579A extending between the Gauss and the late part of the Gilbert epochs (Fig. 8). The overall geometric mean amounts to $1.1 \times 10^{-5} \mathrm{G}$. On average, distinctly higher NRM intensities are observed for samples of normal magnetization polarity $\left(1.7 \times 10^{-5} \mathrm{G}\right)$ than for those carrying a reversed polarity $\left(8.6 \times 10^{-6} \mathrm{G}\right)$. The viscous magnetization components resulting from the present Brunhes field are a plausible explanation for this difference. With a few exceptions, the magnetic stability characterized by the MDF is high (Fig. 8). MDF geometric means for the entire sample collection (278 $\mathrm{Oe})$, normal polarities (270 $\mathrm{Oe})$, and reversed polarities (284 Oe) are essentially identical. Low NRM and MDF values are more abundant in core sections showing clear evidence for intensive drilling disturbance.

The downhole pattern in characteristic remanent magnetization inclination (Fig. 8) reveals a rather high degree of "noise" over various intervals. The variation appears to exceed the normal range of secular field variation in the region during late Cenozoic (see also results of Site 580 ), but seemingly also reflects the limited quality of the materials retrieved at Site 579. Although these effects did not cause specific ambiguities in recognizing magnetic boundaries, in the lower part of Hole 579A gaps in the recovery repeatedly resulted in comparatively large ranges of uncertainty in determining their depth.

The polarity sequence derived from stable inclinations is shown in Figure 8. The two cores recovered in Hole 579 acquired their remanent magnetization during the normal Brunhes Epoch. Therefore, the sediments at the base of this hole (17.9 m sub-bottom) are less than $0.73 \mathrm{~m}$.y. old. An almost complete reversal series for the last about 4.5 m.y. was obtained in Hole 579A. The Brunhes/Matuyama boundary was recognized at a sub-bottom depth of $30.65 \mathrm{~m}$; the Matuyama/Gauss boundary at $87.95 \mathrm{~m}$, and the Gauss/Gilbert boundary at $115.01 \mathrm{~m}$. In addition to the Jaramillo and Olduvai events, a third short normal polarity zone is recorded within the reversed Matuyama Epoch. Its interpolated numerical age of about $2.14 \mathrm{~m}$.y. suggests a correlation to the "X" event (McDougall, 1977), which was previously identified in marine magnetic anomaly data (Heirtzler et al., 1968; Emilia and Heinrichs, 1972). Both the Kaena and Mammoth events are present in the Gauss Epoch, indicating that the paleomagnetic record is also continuous and complete in this part of the hole. The deepest unequivocally identifiable magnetic boundary is the Gauss/Gilbert transition. Beneath, only one additional zone of normal polarity occurs. The interpretation given in Table 4 and Figure 9 relates this interval to the Nunivak Event, assum- ing that the Cochiti Event was lost in the 2.5-m gap in recovery between Cores 13 and 14 . The alternative solution, its correlation to the Cochiti Event, would require a major change in sedimentation rate around this level. The average apparent accumulation rate at Site $\mathbf{5 7 9}$ is about $34.0 \mathrm{~m} / \mathrm{m}$.y. It gradually decreases from $42.0 \mathrm{~m} /$ m.y. during the Brunhes to $32.9 \mathrm{~m} / \mathrm{m}$.y. and $29.1 \mathrm{~m} /$ m.y. in the Matuyama and Gauss epochs, respectively. Compared to other sites drilled on Leg 86 , the late Cenozoic sedimentation rates at Site 579 are somewhat more variable, apparently a result of real fluctuations in the sediment supply.

\section{Site $\mathbf{5 8 0}$}

At Site 580 about $155 \mathrm{~m}$ of Quaternary to late Pliocene biosiliceous clays containing numerous ash layers over the entire sedimentary column were penetrated (Fig. 1). A high percentage recovery was achieved with comparatively minor coring disturbances.

The paleomagnetic sampling program provided approximately 360 vertically oriented specimens. In the upper $\sim 120 \mathrm{~m}$ comprising the record of the geomagnetic Brunhes and Matuyama epochs, there is a systematic decrease in the NRM intensity from about $4 \times 10^{-5}$ to some $5 \times 10^{-6} \mathrm{G}$ (Fig. 10). Below this level to the base of the hole, in the Gauss Epoch, on average slightly higher NRM intensities of about $10^{-5} \mathrm{G}$ were encountered again. The NRM values vary by at least one order of magnitude within virtually all of the cores. Their overall geometric mean amounts to $1.7 \times 10^{-5} \mathrm{G}$. The conspicuous difference in normal $\left(2.4 \times 10^{-5} \mathrm{G}\right)$ and reversed $\left(1.2 \times 10^{-5} \mathrm{G}\right)$ polarities should mainly reflect contributions of viscous magnetization components acquired in the Brunhes Epoch of normal Earth's field configuration. Detailed shore-based analyses using progressive stepwise demagnetization in alternating fields revealed a remarkably high constant magnetic stability throughout. The overall geometric mean for the MDF is 278 Oe and almost the same values were obtained for normal (268 Oe) and reversed (289 Oe) polarities, indicating that the magnetic mineral assemblage should be essentially uniform in composition and grain size. Only minor directional changes are observed between NRM and stable inclinations and declinations upon AF demagnetization. This is practically independent of the respective magnetization polarity (Fig. 2). The general variation in the inclination data throughout the hole apparently results from a normal range of secular paleofield variation. In contrast, the stable declination pattern is much more complex, as it frequently includes variable amounts of disturbances introduced by the coring process.

All magnetic reversal boundaries could be recognized unequivocally. As none of the major polarity transitions coincides with a core boundary and almost no magnetization directions appear to have recorded true transitional Earth field states, it was possible to define an accurate depth position for each reversal boundary. Therefore, the magnetostratigraphic sequence obtained (Table 5 ) is superior in quality to the other Leg 86 paleomagnetic results. The polarity pattern derived from the down- 
U. BLEIL



Figure 8. Stratigraphic column of Holes 579 and 579A. See caption of Figure 5 for details. 
Table 4. Magnetostratigraphy of Holes 579 and 579B.

\begin{tabular}{|c|c|c|c|}
\hline Boundary & $\begin{array}{l}\text { Age }^{\mathrm{a}} \\
(\mathrm{m} . \mathrm{y} .)\end{array}$ & $\begin{array}{c}\text { Polarity transition }{ }^{\mathrm{b}} \\
\text { (Core, Section, level in } \mathrm{cm} \text { ) }\end{array}$ & $\begin{array}{l}\text { Sub-bottom } \\
\text { depthc } \\
\text { (m) }\end{array}$ \\
\hline Brunhes/Matuyama & 0.73 & $2-5,90$ to $2-5,140$ & 30.65 \\
\hline \multicolumn{4}{|l|}{ Jaramillo } \\
\hline top & 0.91 & $3-4,70$ to $3-5,10$ & 38.65 \\
\hline bottom & 0.98 & $3-5,60$ to $3-5,110$ & 39.85 \\
\hline \multicolumn{4}{|l|}{ Olduvai } \\
\hline top & 1.66 & $6-1,31$ to $6-1,55$ & 61.93 \\
\hline bottom & 1.88 & $6-3,85$ to $6-3,140$ & 65.63 \\
\hline Matuyama/Gauss & 2.47 & $8-5,131$ to $8-6,9$ & 87.95 \\
\hline \multicolumn{4}{|l|}{ Kaena } \\
\hline top & 2.92 & $9-5,120$ to $10-1,33$ & 98.52 \\
\hline bottom & 2.99 & $10-3,51$ to $10-3,91$ & 103.21 \\
\hline \multicolumn{4}{|l|}{ Mammoth } \\
\hline top & 3.08 & $10-4,51$ to $10-4,91$ & 104.71 \\
\hline bottom & 3.18 & $10-5,121$ to $11-1,13$ & 107.92 \\
\hline Gauss/Gilbert & 3.40 & $11-4,130$ to $11-5,21$ & 115.01 \\
\hline \multicolumn{4}{|l|}{ Cochiti } \\
\hline top & 3.88 & - & - \\
\hline bottom & 3.97 & - & - \\
\hline \multicolumn{4}{|l|}{ Nunivak } \\
\hline top & 4.10 & $13-5,61$ to $14-1,64$ & 136.38 \\
\hline bottom & 4.24 & $14-3,121$ to $14-4,18$ & 141.95 \\
\hline
\end{tabular}

Note: - means not recovered.

a Berggren et al. (in press).

$\mathrm{b}$ Range reflects uncertainty in determination.

c From coring summary, see Table 1 of Site 579 chapter (this volume). hole variation in stable inclination is shown in Figure 10. It spans most of the last three geomagnetic epochs (Fig. 11). The Brunhes/Matuyama boundary was recognized at $40.00 \mathrm{~m}$ sub-bottom, the Matuyama/Gauss boundary at $121.44 \mathrm{~m}$ below seafloor. In addition to the Jaramillo and Olduvai events, the reversed Matuyama Epoch also comprises the recording of two short polarity events. However, they are both documented by only one data point at present. Although each reversal is clearly indicated in stable inclination and declination, this does not exclude the possibility of an accidental misorientation during sampling. The younger event at about $58 \mathrm{~m}$ sub-bottom, corresponding to an age of about $1.1 \mathrm{~m} . \mathrm{y}$., could not be identified in any other Leg 86 sedimentary column. However, there are indications of such a short reversal or possibly field excursion in pelagic sediments from the Central Pacific (e.g., Forster and Opdyke, 1970), and it is apparently also recorded in a piston core (V3651P) recovered near Site 576 during the Vema-36 presite survey cruise (C. Barton, pers. comm., 1981).

For the event at about $98 \mathrm{~m}$ sub-bottom between the Olduvai and the Matuyama/Gauss boundary, an age of about $2.05 \mathrm{~m}$.y. is interpolated assuming a constant sedimentation rate in this interval. It therefore should represent the Réunion Event (McDougall and Watkins, 1973). In the normal Gauss Epoch, both the Kaena and Mammoth events are clearly recognizable in the magnetostra-

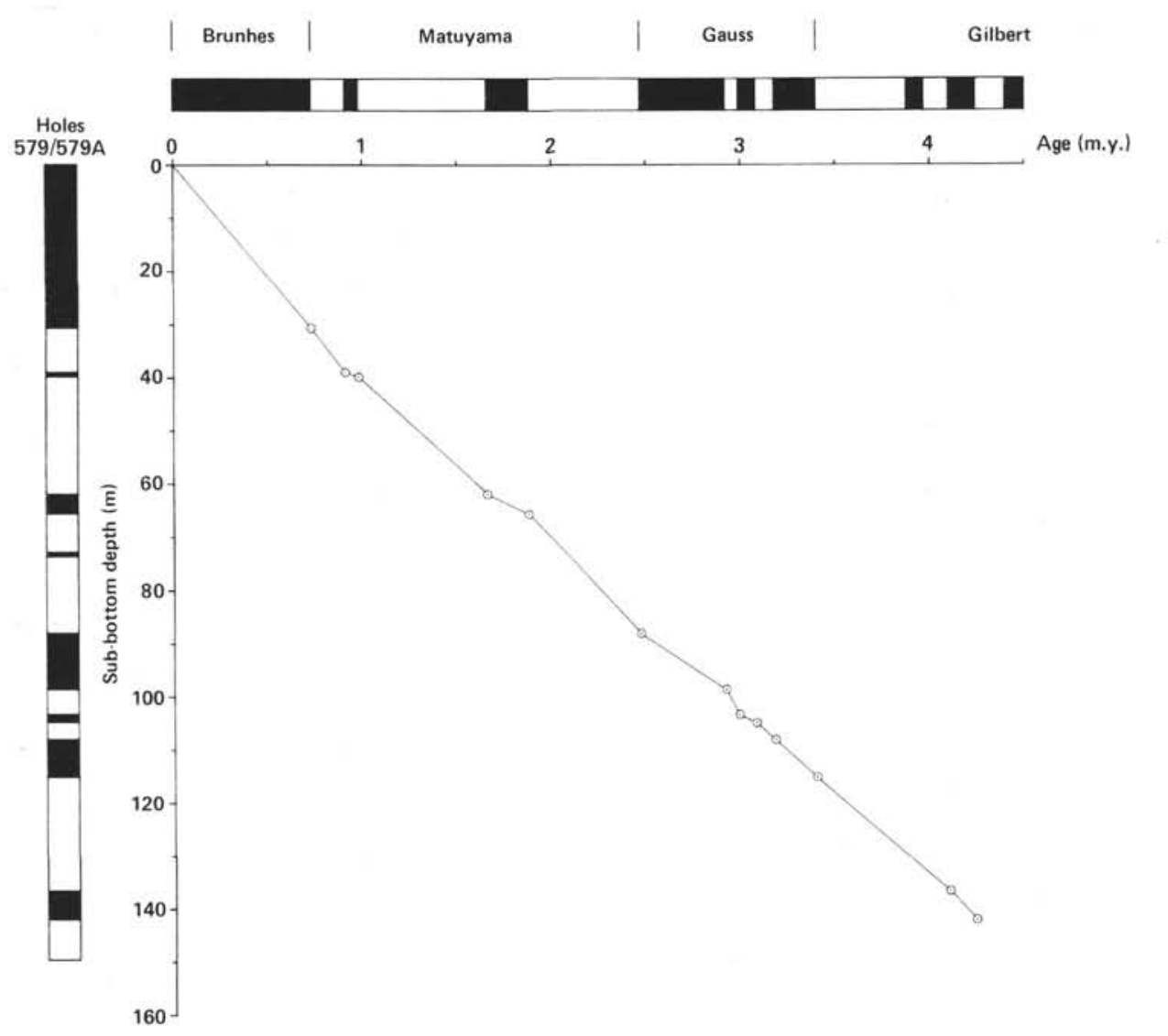

Figure 9. Apparent sediment accumulation at Site 579. The downhole pattern in remanent magnetization polarity is correlated with the geomagnetic polarity time scale of Berggren et al. (in press). Geomagnetic time units (epochs, events) according to McDougall (1977). 
U. BLEIL

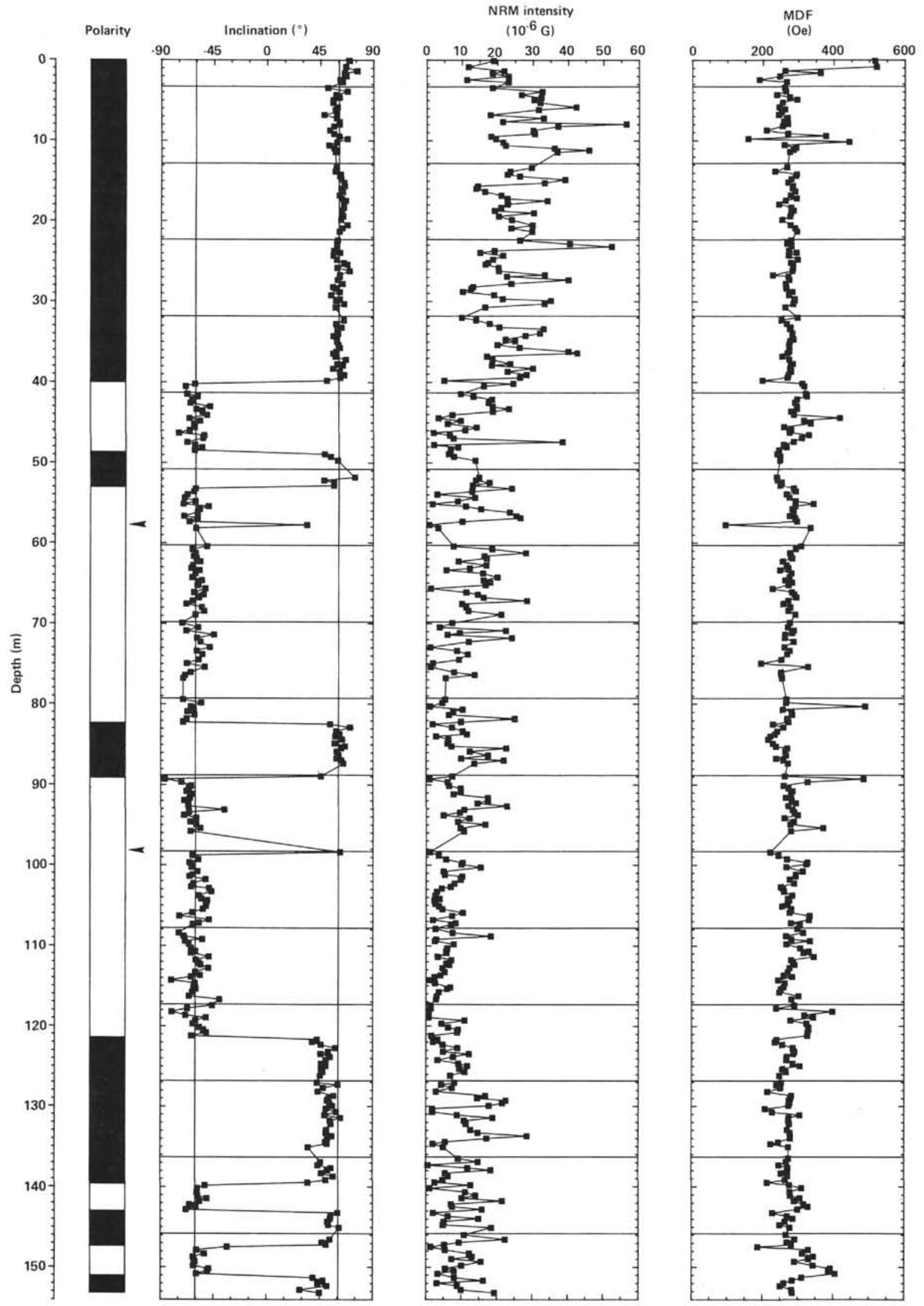

Figure 10. Stratigraphic column of Hole 580. See caption of Figure 5 for details. 
Table 5. Magnetostratigraphy of Hole 580 .

\begin{tabular}{|c|c|c|c|}
\hline Boundary & $\begin{array}{l}\text { Agea }^{a} \\
\text { (m.y.) }\end{array}$ & $\begin{array}{c}\text { Polarity transition }{ }^{\mathrm{b}} \\
\text { (Core, Section, level in } \mathrm{cm} \text { ) }\end{array}$ & $\begin{array}{l}\text { Sub-bottom } \\
\text { depthc } \\
\text { (m) }\end{array}$ \\
\hline $\begin{array}{l}\text { Brunhes/Matuyama } \\
\text { Jaramillo }\end{array}$ & 0.73 & $5-6,50$ to $5-6,90$ & 40.00 \\
\hline top & 0.91 & $6-5,114$ to $6-6,13$ & 48.69 \\
\hline bottom & 0.98 & $7-2,54$ to $7-2,92$ & 53.03 \\
\hline \multicolumn{4}{|l|}{ Olduvai } \\
\hline top & 1.66 & $10-2,140$ to $10-3,15$ & 82.33 \\
\hline bottom & 1.88 & $11-1,15$ to $11-1,50$ & 89.13 \\
\hline Matuyama/Gauss & 2.47 & $14-3,91$ to $14-3,136$ & 121.44 \\
\hline \multicolumn{4}{|l|}{ Kaena } \\
\hline top & 2.92 & $16-3,15$ to $16-3,51$ & 139.63 \\
\hline bottom & 2.99 & $16-5,51$ to $16-5,91$ & 143.01 \\
\hline \multicolumn{4}{|l|}{ Mammoth } \\
\hline top & 3.08 & $17-1,141$ to $17-2,15$ & 147.33 \\
\hline bottom & 3.18 & $17-4,51$ to $17-4,101$ & 151.06 \\
\hline
\end{tabular}

a Berggren et al. (in press).

b Range reflects uncertainty in determination.

c From coring summary, see Table 1 of Site 580 chapter (this volume).

tigraphic record. The base of the hole at $155.30 \mathrm{~m}$ below seafloor did not reach the Gauss/Gilbert reversal boundary.

The entire sediment column at Site 580 accumulated at a remarkably constant average rate of about $47.5 \mathrm{~m}$./ m.y. (Fig. 11). Downhole, it only decreases from about $54.8 \mathrm{~m} / \mathrm{m} . \mathrm{y}$. during the Brunhes Epoch to $46.8 \mathrm{~m} / \mathrm{m}$.y. in the Matuyama Epoch and $41.7 \mathrm{~m} / \mathrm{m}$.y. in the Gauss
Epoch. Extrapolation yields an age of about 3.30 m.y. at the base of the hole. The high sedimentation rates facilitate determination of a detailed sequence of transitional configurations of the Earth's magnetic field during several reversals. The results of this study will be reported elsewhere.

\section{PALEOLATITUDES}

Any evaluation of paleolatitudes from paleomagnetic data of DSDP drill cores is known to have specific limitations (Pierce, 1976). Those limitations mainly result from the drilling process (disturbed or incomplete recovery and undetected oblique coring) and also from the statistical problem of accounting appropriately for the lack in azimuthal orientation of the cores. The development of the HPC technique has reduced these difficulties to some extent and, although no direct measurements were performed during Leg 86 , according to all previous experience, DSDP drill cores should not deviate by more than 2 to $3^{\circ}$ from the vertical. Exactly this same amount of inaccuracy would apply to the inclinations and, at about 30 to $40^{\circ}$ latitude, also to the paleolatitudinal data. Other potential error sources, such as the depositional mode or a compaction of the sediments and an inappropriately averaged secular field variation, should be negligible in the present case. As in most other recent studies on DSDP materials (Tauxe et al., 1984; Weinreich and Theyer, in press), the method developed by Briden

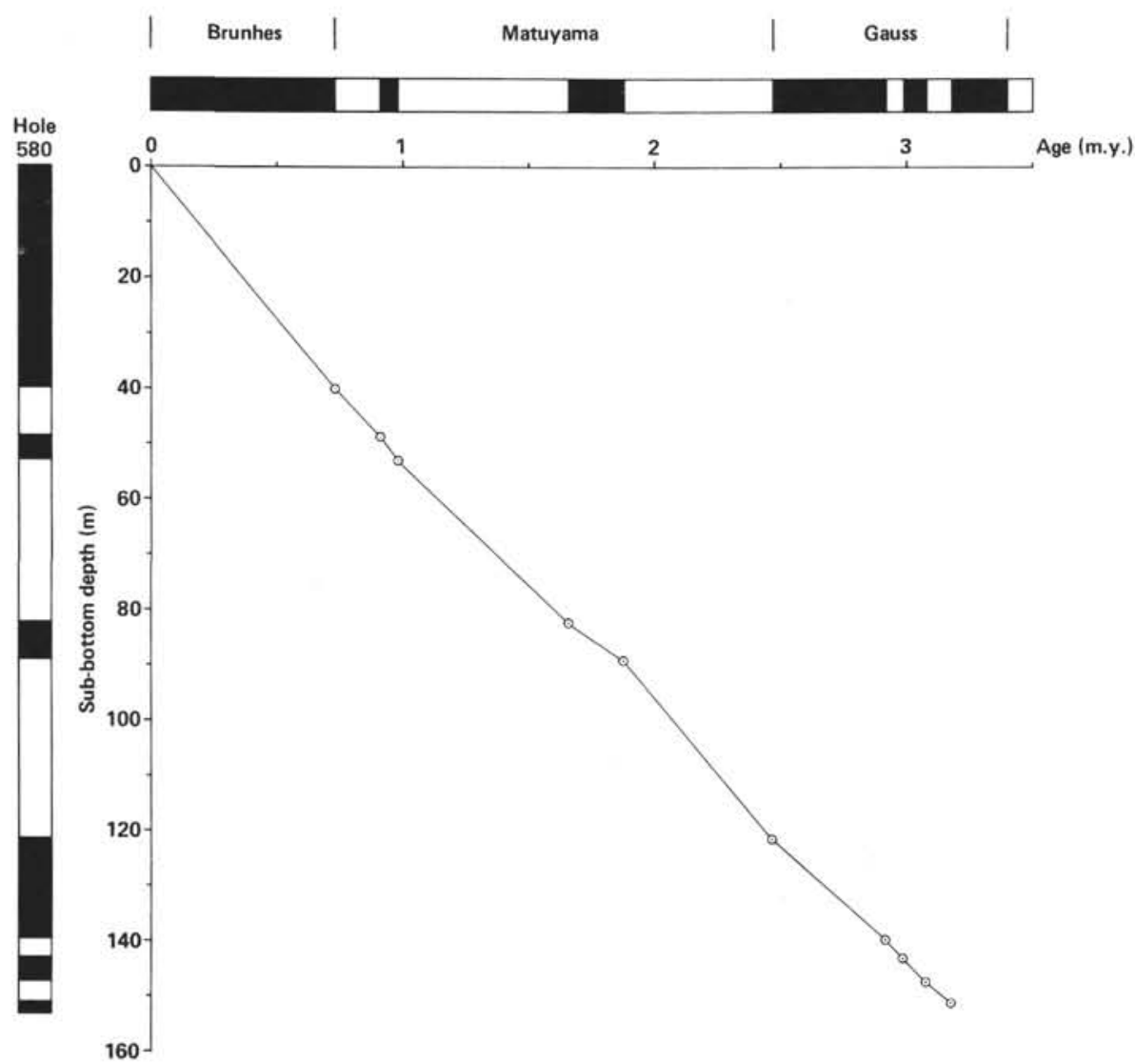

Figure 11. Apparent sediment accumulation at Site 580. See caption of Figure 9 for details. 
and Ward (1966) and refined by Kono (1980) has been used to estimate true mean inclinations from the paleomagnetic data.

The results for the different drill sites are shown in Figures 12 through 14 . In the late Cenozoic, average paleolatitudes were determined for each geomagnetic epoch. The $95 \%$ errors of the paleolatitudes, as resulting from the Kono (1980) statistics, are typically on the order of $\pm 2-3^{\circ}$. At none of the sites do mean values indicate simple continuous trends, which could unequivocally be interpreted in terms of plate motions.

According to plate tectonic models derived from hotspot analysis (Epp, 1978), the north component of the

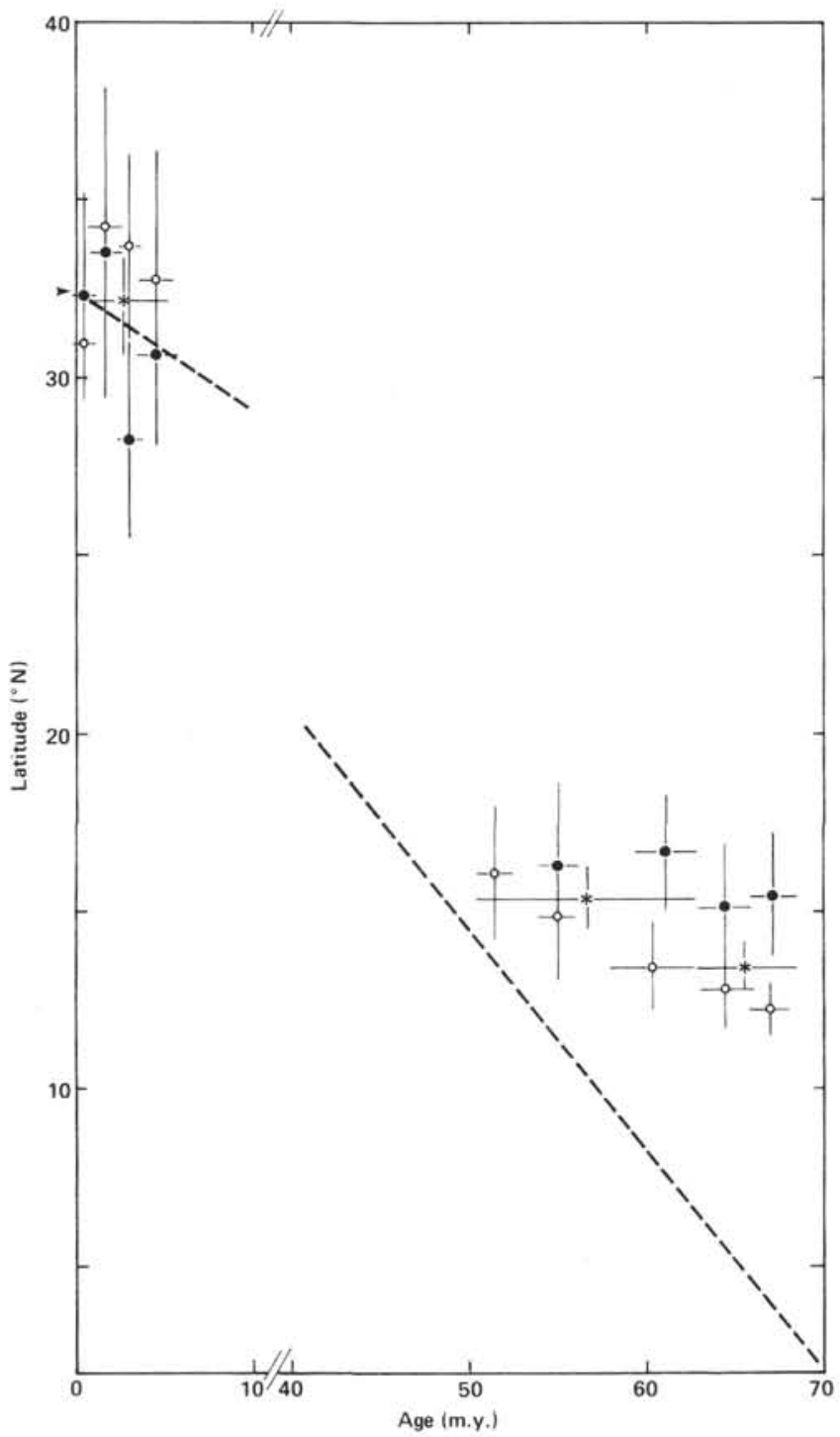

Figure 12. Age dependence of paleolatitude for Site 577 as derived from the downhole variation in inclination of the characteristic remanent magnetization of sediments. $\bigcirc$ Hole 577, Hole 577A, * Holes 577/577A combined. Vertical error bars represent the latitudinal dispersion as resulting from the Kono (1980) statistics, horizontal error bars denote the averaged time intervals corresponding to geomagnetic epochs in the late Cenozoic. The arrow indicates the present latitude of Site 577, the broken line its progressive north. ward motion since the Late Cretaceous as quantified by plate tectonic reconstructions (Epp, 1978).
Pacific plate motion has been about $0.3^{\circ} / \mathrm{m}$.y. during the last about $15 \mathrm{~m} . \mathrm{y}$. The Pliocene to Quaternary paleomagnetic records obtained at Sites 577, 579, and 580, therefore, obviously extend over too short a period of time to allow any significant contribution to this problem, in view of their inherent statistical accuracy and even without additional systematic errors.

A puzzling and as yet unexplained feature is the remarkable difference in inclination and thus in paleolatitude for normal and reversed magnetizations in the deepest four cores of Hole 580 (Fig. 10). It evidently can not be caused by a nonvertical drill hole. Also, because of the high magnetic stability and the well-defined demagnetiza-

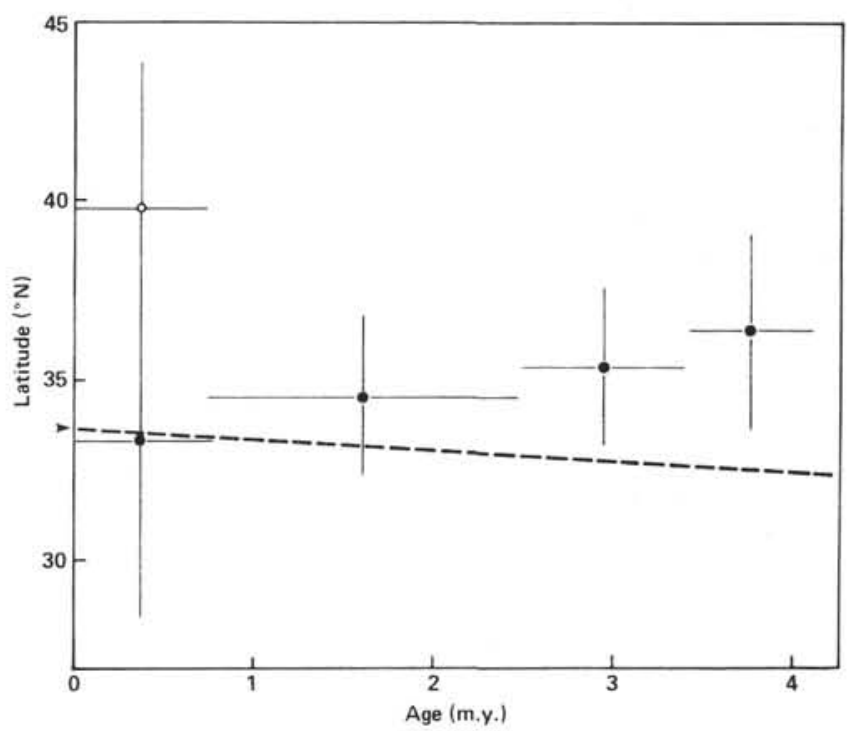

Figure 13. Age dependence of paleolatitude for Site 579 as derived from the downhole variation in inclination of the characteristic remanent magnetization of sediments. $\bigcirc$ Hole 579, Hole 579A. See caption of Figure 12 for details.

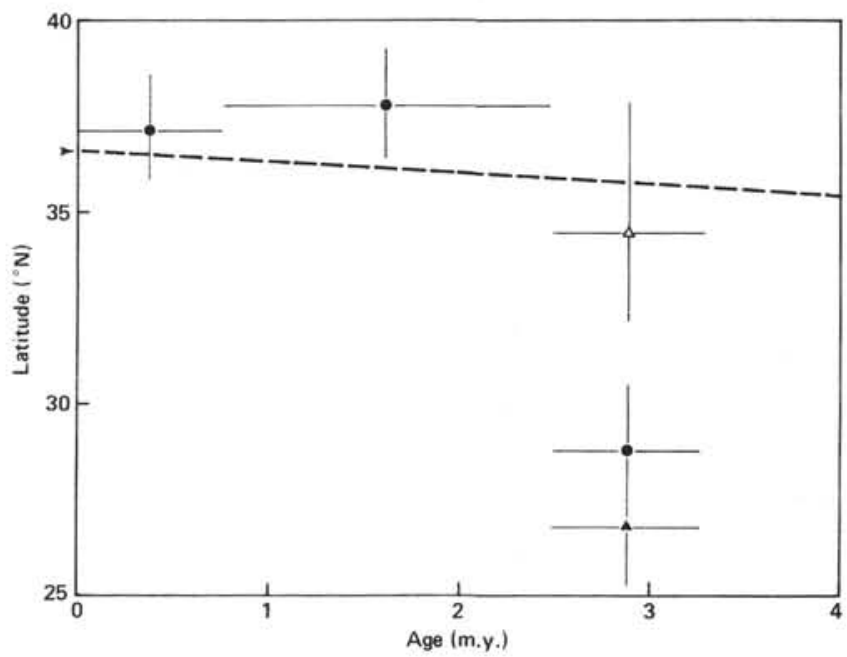

Figure 14. Age dependence of paleolatitude for Site 580 (O) as derived from the downhole variation in inclination of the characteristic remanent magnetization of sediments. As shown, normal $(\mathbf{A})$ and reversed $(\triangle)$ polarity intervals result in significantly different paleolatitudes for the Gauss Epoch. See Figure 12 for details. 
tion characteristics of these samples, an undetected overprinting by secondary components appears rather unlikely. On the other hand, similar behavior is not observed in the relevant intervals at the other sites.

For Late Cretaceous to middle Eocene sequences recovered in the lower halves of both holes at Site 577, the characteristic remanent magnetization inclination is distinctly shallower than the centered axial dipole value for the present latitude of the site (Figs. 5 and 6), providing clear evidence for the major unconformity at around $60 \mathrm{~m}$ sub-bottom. They suggest a northward motion of this part of the Pacific plate of about $17^{\circ}$ between about 50 and $5 \mathrm{~m} . \mathrm{y}$. ago. The same order of magnitude is inferred from a hot-spot analysis (Epp, 1978), the most elaborate basis for a plate tectonic reconstruction of the region at present (J. Morgan, pers. comm., 1983). However, according to the latter data, the Pacific plate has moved with an average north component of $0.75^{\circ} / \mathrm{m}$.y. in the period between 70 and 50 m.y. ago, whereas the present results would give less than half this value (Fig. 12). As discussed in detail before, there are some indications that the paleomagnetic data may not be of prime quality in this interval. Nevertheless, the altogether convincing magnetostratigraphy obtained is not really compatible with an almost equatorial position of Site 577 in the Late Cretaceous and early Tertiary. A more complete treatment of the various aspects of these problems will be given elsewhere.

\section{CONCLUSIONS}

The paleomagnetic analyses of biosiliceous and calcareous sedimentary columns recovered on DSDP Leg 86 in the Northwest Pacific are a valuable aid in resolving the stratigraphic record of the deep sea in this area. Detailed Pliocene to Recent magnetostratigraphies were established at all drill sites, comprising major parts or the complete sequences of Earth's magnetic field reversals during the last four geomagnetic epochs. The magnetostratigraphies of Late Cretaceous to middle Eocene sediments penetrated in stratigraphic duplication at Site 577 (on the Shatsky Rise) using HPC could successfully be correlated to marine magnetic anomaly series and recent paleomagnetic results on pelagic sections from different parts of the world. These data constitute the first opportunity to elaborate a magnetobiochronology for this period, including the Cretaceous/Tertiary boundary interval, in the Pacific (Monechi et al., this volume).

For each site a diagrammatic apparent sedimentation rate based on the magnetostratigraphy is presented. Paleolatitudes derived from the variations in characteristic remanent magnetization inclination with age have a bearing on the northward motion of the Pacific plate. The data, however, show rather large discrepancies with existing plate tectonic models, presumably reflecting the still limited suitability of DSDP materials for such studies.

\section{ACKNOWLEDGMENTS}

I am very grateful to the many people responsible for the success of DSDP Leg 86, in particular to my scientific colleagues for their friendly cooperation. Special appreciation is given to V. Spiess and N. Weinreich for their help with the laboratory work, discussions, and valuable comments. W. Lowrie and an anonymous reviewer critically reviewed drafts, materially improving the manuscript.

The financial support of the Deutsche Forschungsgemeinschaft both toward the Deep Sea Drilling Project and the paleomagnetic laboratory in Bochum is gratefully acknowledged.

\section{REFERENCES}

Alvarez, W., Arthur, M. S., Fischer, A. F., Lowrie, W., Napoleone, G., Premoli Silva, I., and Roggenthen, W. M., 1977. Type section for the Late Cretaceous-Paleocene geomagnetic reversal time scale. Geol. Soc. Am. Bull., 88:383-389.

Alvarez, W., and Lowrie, W., 1978. Upper Cretaceous paleomagnetic stratigraphy at Moria (Umbrian Apennines, Italy): Verification of the Gubbio section. Geophys. J. R., Astron. Soc., 55:1-17.

Berggren, W. A., Kent, D. V., and Flynn, J. J., in press. Paleogene geochronology and chronostratigraphy. In Snelling, N. J. (Ed.), Geochronology and the Geological Record. Geol. Soc. London, Spec. Publ.

Briden, J. C., and Ward, M. A., 1966. Analysis of magnetic inclinations in bore cores. Pure Appl. Geophys., 63:133-152.

Chave, A., 1984. Lower Paleocene-Upper Cretaceous magnetostratigraphy, Sites 525, 527, 528, and 529, Deep Sea Drilling Project Leg 74. In Moore, T. C., Jr. Rabinowitz, P. D., et al., Init. Repts. DSDP, 74: Washington (U.S. Govt. Printing Office), 525-531.

Emilia, D. A., and Heinrichs, D. F., 1972. Palaeomagnetic events in the Brunhes and Matuyama epochs identified from magnetic profiles reduced to the pole. Mar. Geophys. Res., 1:436-444.

Epp, D., 1978. Age and tectonic relationship among volcanic chains on the Pacific plate. [Ph. D. dissert.]. University of Hawaii, Honolulu.

Foster, J. H., and Opdyke, N. D., 1970. Upper Miocene to Recent magnetic stratigraphy in deep-sea sediments. J. Geophys. Res., 75: 4465-4473.

Hedberg, H. D., Salvador, A., and Opdyke, N. D., 1979. Magnetostratigraphic polarity units-A supplement chapter of the ISSC International Stratigraphic Guide. Geology, 7:578-583.

Heirtzler, J. R., Dickson, G. O., Herron, E. M., Pitman, W. C., III, and Le Pichon, X., 1968. Marine magnetic anomalies, geomagnetic field reversals and motions of the ocean floor and continents. $J$. Geophys. Res., 73:2119-2136.

Hoffman, K. A., and Day, R., 1978. Separation of multi-component NRM, a general method. Earth Planet. Sci. Lett., 40:433-438.

Hsü, K. J., He, Q., McKenzie, J. A., Weissert, H., Perch-Nielsen, K., Oberhänsli, H., Kelts, K., LaBrecque, J., Tauxe, L., Krähenbühl, U., Percival, S. F., Jr., Wright, R., Karpoff, A. M., Petersen, N., Tucker, P., Poore, R. Z., Gombos, A. M., Pisciotto, K., Carman, M. F., Jr., and Schreiber, E., 1982. Mass mortality and its environmental and evolutionary consequences. Science, 216:249-256.

Kent, D. V., and Lowrie, W., 1974. Origin of magnetic instability in sediment cores from the central north Pacific. J. Geophys. Res., 79:2987-3000

Kent, D. V., and Spariosu, D. J., 1982a. Magnetostratigraphy of Carribean Site 502 hydraulic piston cores. In Prell, W. L., Gardner, J. V., et al., Init. Repts. DSDP, 68: Washington (U.S. Govt. Printing Office), 419-433.

1982b. Magnetostratigraphy of equatorial Pacific Site 503 hydraulic piston cores. In Prell, W. L., Gardner, J. V., et al., Init. Repts. DSDP, 68: Washington (U.S. Govt. Printing Office), 435440.

Kono, M., 1980. Statistics of paleomagnetic inclination data. J. Geophys. Res., 85:3878-3882.

LaBrecque, J. L., Kent, D. V., and Cande, S. C., 1977. Revised magnetic polarity time scale for Late Cretaceous and Cenozoic time. Geology, 5:330-335.

McDougall, I., 1977. The present status of the geomagnetic polarity time scale. Research School of Earth Sciences, A.N.U., Publ. No. 1288.

McDougall, I., and Watkins, N. D., 1973. Age and duration of the Réunion geomagnetic polarity event. Earth Planet. Sci. Lett., 19: 443-452.

Opdyke, N. D., 1972. Paleomagnetism of deep-sea cores. Rev. Geophys. Space Phys., 10:213-249.

Pierce, J. W., 1976. Assessing the reliability of DSDP paleolatitudes. J. Geophys. Res., 81:4173-4187. 
Prince, R. A., Heath, G. R., and Kominz, M., 1980. Paleomagnetic studies of central North Pacific sediment cores: Stratigraphy, sedimentation rates, and the origin of magnetic instability. Geol. Soc. Am. Bull., 91(Part II):1789-1835.

Shackleton, N. J., and Shipboard Scientific Party, 1984. Accumulation rates in Leg 74 sediments. In Moore, T. C., Jr., Rabinowitz, P. D., et al., Init. Repts. DSDP, 74: Washington (U.S. Govt. Printing Office), 621-644.

Tauxe, L., Tucker, P., Petersen, N., and LaBrecque, J. L., 1984. Magnetostratigraphy of Leg 73 sediments. In Hsü, K. J., LaBrecque, J. L., et al., Init. Repts. DSDP, 73: Washington (U.S. Govt. Printing Office), 609-622.
Thierstein, H. R., 1982. Terminal Cretaceous plankton extinction: A critical assessment. Geol. Soc. Am. Spec. Pap., 190:385-399.

Weinreich, N., and Theyer, F., in press. Paleomagnetism of the Leg 85 sediments: Neogene magnetostratigraphy and tectonic history of the Central Equatorial Pacific. In Mayer, L., Theyer, F., et al., Init. Repts. DSDP, 85: Washington (U.S. Govt. Printing Office).

Zijderveld, J. D. A., 1967. A.C. demagnetization of rocks: analysis of results. In Collison, D. W., Creer, K. M., and Runcorn, S. K. (Eds.), Methods in Palaeomagnetism: Amsterdam (Elsevier), pp. 254-286.

Date of Initial Receipt: 3 January 1984

Date of Acceptance: 18 June 1984 